\title{
$\mathrm{ETF}$ 와 블랙리터만 모형을 이용한 인핸스드 인덱스 전략*
}

\author{
박기경** . ${ }^{\dagger}$ 이영호** - 서지원**

\section{Enhanced Indexation Strategy with ETF and Black-Litterman Model}

\author{
Gigyoung Park ${ }^{* *} \cdot{ }^{\dagger}$ Youngho Lee** $\cdot$ Jiwon Seo**
}

\begin{abstract}
In this paper, we deal with an enhanced index fund strategy by implementing the exchange trade funds (ETFs) within the context of the Black-Litterman approach. The KOSPI200 index ETF is used to build risk-controlled portfolio that tracks the benchmark index, while the proposed Black-Litterman model mitigates estimation errors in incorporating both active investment views and equilibrium views. First, we construct a Black-Litterman model portfolio with the active market perspective based on the momentum strategy. Then, we update the portfolio with the KOSPI200 index ETF by using the equilibrium return ratio and weighted averages, while devising optimization modeling for improving the information ratio (IR) of the portfolio. Finally, we demonstrate the empirical viability of the proposed enhanced index strategies with KOSPI 200 data.
\end{abstract}

Keywords: Enhanced Index Funds, Black-Literman Model, Exchange Trade Funds, Information Ratio, Momentum Strategy

\footnotetext{
논문접수일 : 2013년 05월 28일 논문게재확정일 : 2013년 08월 09일 논문수정일 : 2013년 08월 06일

* 이 논문은 2011년과 2012년도 정부(교육과학기술부)의 재원으로 한국연구재단의 지원을 받아 수행된 연구임(NRF2011-0011400, NRF-2012R1A1A2006847). 이 논문은 2단계 두뇌한국(BK)21사업에 의하여 지원됨.

** 고려대학교 산업경영공학부

† 교신저자, yhlee@korea.ac.kr
} 


\section{1. 서 론}

이 논문은 인핸스드 인덱스 펀드(Enhanced Index Fund) 설계를 위한 최적화 모형을 개발한다. 인핸 스드 인덱스 펀드는 목표지수(Benchmark Index) 를 추적하면서 일정 수준의 목표지수 초과수익을 얻는 금융 상품으로, 펀드 운용 전략 측면에서 액 티브(Active) 전략과 패시브(Passive) 전략의 특징 을 동시에 지닌다[3]. 액티브 전략은 종목 발굴, 시 장진입시점 선택, 그리고 섹터 별 자산 배분과 같 은 연구를 통해 목표지수 수익률보다 높은 수익률 을 추구하는 전략이고, 패시브 전략은 펀드매니저 의 자산 선택에 대한 의사결정 없이 목표지수 수익 률을 추구하는 전략이다. 펀드 운용 전략은 <그림 $1>$ (a)와 같이 목표지수 초과 수익과 추적 오차 변 동성를 기준으로 인덱스 투자 전략, 인핸스드 인덱 스 투자 전략, 리스크 조정 액티브 전략, 액티브 퀀 트 전략, 다양화된 액티브 전략, 그리고 액티브 특 화 전략으로 구분된다[24]. 인덱스 투자 전략은 자산 을 상장지수펀드(Exchange Traded Funds, ETFs) 와 같은 지수 관련 상품에 투자하여 목표지수 수익 률을 추구한다. 인핸스드 인덱스 투자 전략은 목표 지수 초과 수익률 $2 \%$ 를 목표로 자산을 운영하며, 목표지수 추적 오차(Tracking Error, TE)를 3\% 이내로 유지하는 투자 전략이다. 이외의 전략은 전 통적인 액티브 전략으로 자산 운용사가 수리모형 을 이용한 정량분석이나 기업방문을 통한 정성분 석를 통해 포트폴리오를 구성하여 높은 초과 수익 률 달성을 목표로 한다. 곽재혁[1]은 시장에서 거 래되는 액티브 펀드와 인핸스드 인덱스 펀드를 비 교하여 목표지수 추적 오차 변동성에 따른 수익률 을 비교하였다. 2004년 1월부터 2007년 10월까지 주식 시장 상승기에 목표지수(KOSPI200)의 수익 률은 $25.18 \%$ 이고, 액티브 펀드의 수익률은 최고 $40.38 \%$ 에서 최저 $20.06 \%$ 이며, 인핸스드 인덱스 펀 드 수익률은 최고 $29.10 \%$ 에서 최저 $24.46 \%$ 였다. 그리고 2007년 11월부터 2009년 2월까지 하락기간에 서 목표지수의 수익률이 $-19.39 \%$ 이고, 액티브 펀
드 수익률은 최고 $-5.6 \%$ 에서 최저 $-28.45 \%$ 이며, 인핸스드 인덱스 펀드 수익률은 최고 $-11.37 \%$ 에서 $-15.24 \%$ 였다. 인핸스드 인덱스 펀드는 상승기에 목 표지수보다 수익률이 우수하고, 하락기에 목표지수 보다 투자에 따른 손실이 적다. 따라서 인핸스드 인덱스 펀드는 수익성을 개선하고 목표지수에 대 한 추적오차 관리가 가능하다. 인덱스 펀드와 인핸 스드 인덱스 펀드를 이용한 자산 운용의 안정성이 입증되면서 ETF 시장규모는 2002년 3,444억 원으 로 출발하여 2012년 14조 2,306억 원으로 크게 성 장하였으며, 거래규모도 매년 크게 증가하고 있다 [8]. 따라서 이 논문은 인핸스드 인덱스 펀드 구성 을 위해 ETF 활용 방안을 개발한다.

인핸스드 인덱스 펀드 구축을 위해 <그림 $1>(\mathrm{b})$ 와 같이 주식현물 전략(Stock-Based Strategies) 과 합성 전략(Synthetic)을 사용한다[9]. 주식현물 전략을 위해 주식을 선정하고 투자 비중을 결정한 다. 투자 비중 결정 방법에는 틸팅(Tilting) 전략과 동일 비중(Equal-Weighted) 전략이 있다. 틸팅 전 략은 인덱스 펀드 투자 비중을 유지하면서, 가치주, 성장주, 배당주와 같이 선호하는 종목스타일이나 섹터에 대해 범위를 제한하고 투자 비중을 조절하 여 목표지수 대비 초과수익을 달성한다. 동일비중 전략은 지수에 포함된 종목에 동일한 가중치를 부 여하여 포트폴리오를 구성한다. 주로 시가총액 별 로 개별종목 가중치를 부여하는 시가총액(Market Weighted) 방식으로 운용한다. 한편 주식 선정을 위한 분석방법론은 정량 분석(Quantitative Analysis)과 펀더멘탈 분석(Fundamental Analysis)이 있다. 정량분석은 시장대비 초과수익률이 기대되는 종목 선정을 위해 이익 성장률, 어닝 서프라이즈(Earning Surprise), 가격모멘텀, 유동성, 가치/성장, 배당 수 익률, 그리고 시가총액과 같은 수치 자료를 이용한 주식 선정 방법이다. 펀더멘탈 분석은 재무구조와 시장 환경과 같은 기업분석을 이용한 주식 선정 방 법으로, 수치 자료보다 경쟁 우위, 수요현황, 그리 고 수익구조와 같은 기업 가치를 바탕으로 주식을 선별한다. 이와 같이 주식현물을 이용한 전략 이외 


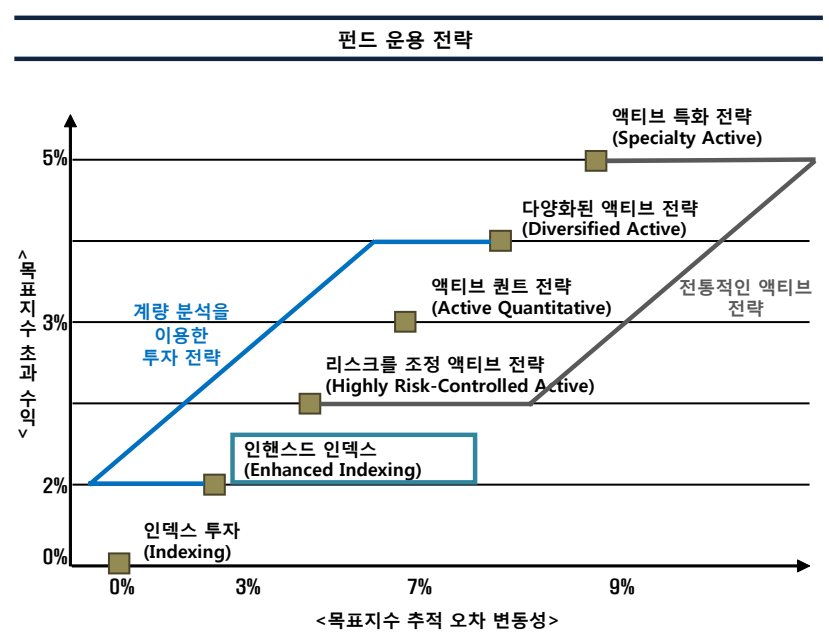

(a) 인핸스트 인덱스 투자 전략의 리스크 수준

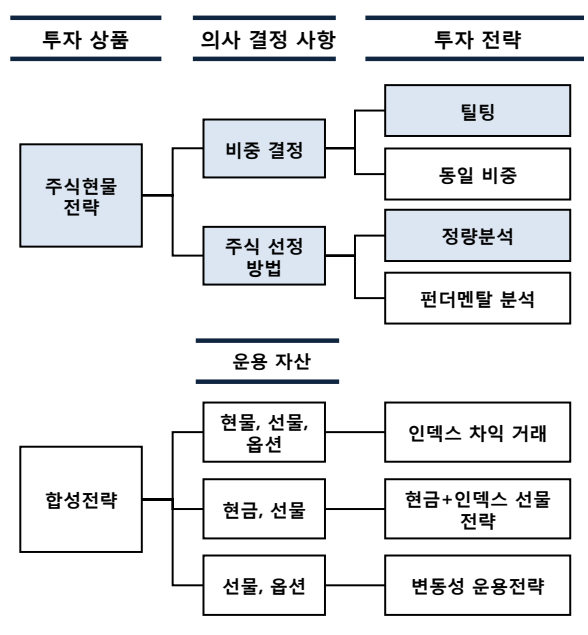

(b) 인핸스트 인덱스 투자 방법

〈그림 1〉인핸스드 인덱스 투자 전략

에도 선물, 옵션, 그리고 스왑과 같은 파생상품을 이용하는 합성 전략이 있다. 파생상품을 활용하는 방법은 운용 자산에 따라 현물, 선물, 그리고 옵션 을 이용하는 인덱스 차익 거래 전략, 현금과 선물 을 이용하는 현금+인덱스 선물 전략, 그리고 선물 과 옵션을 사용하는 변동성 운용전략이 있다. 인덱 스 차익거래 전략은 선물 또는 옵션이 매매비용을 고려한 이론 가격에서 벗어날 경우, 현물과 선물의 고평과와 저평가 관계를 이용하여 차익거래를 한 다. 그리고 현금+인덱스 선물 전략은 선물 보유, 콜매수, 그리고 풋매도를 이용해 지수 전체를 거래 하는 전략이다. 자산의 $15 \%$ 를 인덱스 지수 전체에 투자하여 추적오차를 줄이고, 나머지 $85 \%$ 를 인덱 스 선물의 내재수익률을 초과하는 단기채권, 양도 성예금증서(Certificate of Deposit, CD), 그리고 콜 과 같은 단기 자금으로 운영하여 초과수익률을 추 구한다. 마지막으로 변동성 운용전략은 장기투자 관점에서 단기적으로 주가가 크게 오른 자산은 시 장 노출정도(Exposure)를 줄이고, 시장이 급락한 상황에서 시장 노출정도를 늘려 주가의 평균회귀 (Reversion to the Mean) 성질을 이용하는 전략이 다. 이 논문은 주식현물 전략을 사용하여 인핸스드 인덱스 펀드를 구성한다. 그리고 효율적인 초과 수
익률 달성을 위해 틸팅 전략을 사용하며 주식 선정 을 위해 정량분석을 이용한다.

틸팅을 이용한 인핸스드 인덱스 전략의 목표는 $<$ 그림 $2>(\mathrm{a})$ 와 같이 목표지수 추적과 목표지수 초 과 수익률 달성이다. 목표지수 추적을 위해 KOSPI 200 을 복제하는 ETF를 이용하고 목표지수 초과 수익 달성을 위해 액티브 포트폴리오를 구성한다. 액티브 포트폴리오 구성을 위해 금융시장에서 자 산 선호도를 나타내는 랭킹을 이용한다. 랭킹은 불 확실한 상황에서 자산의 상대적 선호도를 나타내 며 수익률과 양의 상관관계를 갖는다. 예를 들어 $\mathrm{A}$ 주식의 랭킹이 2이고, $\mathrm{B}$ 주식의 랭킹이 5이면, $\mathrm{A}$ 주식이 $\mathrm{B}$ 주식 보다 기대수익률이 높다는 것을 의 미하며, 두 주식 간 기대수익률 차이 정보는 갖지 않는다. <그림 $2>(\mathrm{b})$ 와 같이 자산의 랭킹을 결정 하는 요인으로 변동성, 모멘텀, 시가총액, 거래량, 성장률, 이익률과 같은 자산 선별 요인을 선정하 고, 이러한 요인을 근거로 자산의 랭킹을 계산한 다. 일반적으로 정량분석을 이용하여 수익률에 영향을 주는 요인을 분석하며, 선형 모형이나 비 선형 모형과 같은 수리 모형을 이용한다. 랭킹을 이용한 투자 전략은 국내외 금융회사에서 널리 이 용하는 투자 전략이다. 예를 들어 외국계 투자 컨 


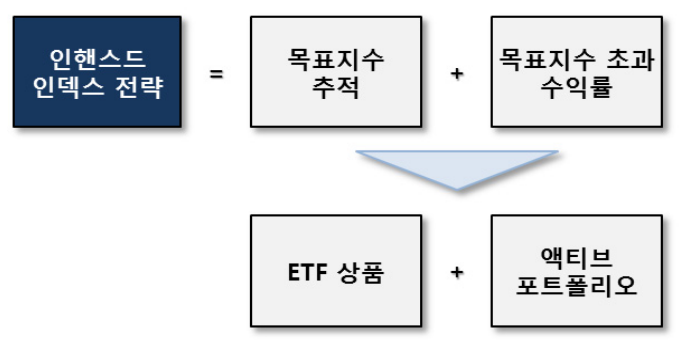

(a) ETF 상품을 이용한 틸팅 전략
자산 선별 요인

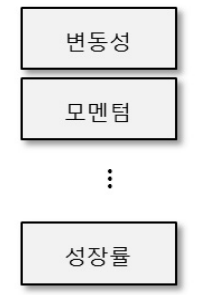

랭킹 부여

랭킹1: 주식 1

랭킹2: 주식 2

$\vdots$

랭킹3: 주식 n

〈그림 2〉 주식을 이용한 인핸스드 인덱스 전략 : 틸팅전략과 랭킹을 이용한 자산 선정

설팅 회사인 Financial Factory[14]과 Super Stock Screener[22]는 랭킹을 이용하여 투자 전략을 세운 다. Financial Factory는 주식을 분석하여 Rank \#1 매수 그룹과 Rank \#5 매도 그룹을 분류한 후 매도 /매수 전략을 세워 포트폴리오를 구성하며, Super Stock Screener는 랭킹을 1그룹부터 5그룹까지 분 류하여 랭킹 포트폴리오를 구성하고 투자 전략을 세운다. 이러한 틸팅 전략과 랭킹을 고려하여 투자 자산을 선정하고 투자 비중을 결정하기 위해 자산 배분모형(Asset Allocation Model)이 필요하다.

자산배분 모형에 대한 연구는 Markowitz가 제안 한 평균분산 모형에서 시작된다[19]. 평균분산 모형 은 위험을 일정 수준으로 제한하고, 기대수익률을 최대화하는 포트폴리오 설계 모형이다. 평균분산 모 형은 수리 모형을 이용한 포트폴리오 설계의 기틀을 마련하였으며, 포트폴리오 최적화 모형 발전의 기반 이 되었다. 그러나 현실에서 평균분산 모형을 이용할 경우, 최적화 모형에 따른 코너해(Corner Solution) 현상, 민감도 문제, 모수 추정 오류에 따른 자산 편 중 현상이 나타난다[16]. 실제 데이터를 이용하여 평균분산 모형의 해를 구할 경우, 코너해가 발생하 여 일부 자산에 투자 비중이 편중되는 현상이 발생 한다. 따라서 분산 투자를 통해 개별 자산이 가진 위험을 축소하는 분산 투자 효과가 적다. 평균분산 모형에 입력되는 모수는 민감도가 크기 때문에, 일 정 기간 간격으로 포트폴리오를 재구성할 때 거래 비용이 크게 발생한다. 그리고 수익률과 분산과 같 은 통계 값은 샘플 데이터에 대한 추정값이기 때문
에 모수 추정의 오류로 인해 투자 자산이 편중된 포 트폴리오를 구성할 가능성이 높다. 이러한 문제점으 로 인해 투자자는 현업에서 평균분산 모형을 이용하 여 포트폴리오를 구성하기 어렵다. 평균분산이 가진 문제점을 극복하기 위해 Black and Litterman[11, 12] 은 블랙리터만 모형을 개발하였다. 블랙리터만 모형 은 균형기대수익률 계산, 투자자 전망 결합, 그리고 평균분산 모형을 이용한 자산 비중 결정으로 구성 된다. 균형기대수익률은 시장에 내재된 기대수익률 로, 평균분산 모형에 대입하면 주식시장의 시가총액 비중과 같은 해가 도출된다. 그리고 투자 시점에서 균형기대수익률과 투자자 전망을 베이지안 방법으 로 결합하여, 블랙리터만 수익률을 계산한다[23]. 이 런 방법으로 계산한 블랙리터만 수익률을 평균분산 모형에 대입하여 포트폴리오를 구성하는 방법론을 블랙리터만 모형이라 한다. 블랙리터만 모형은 투자 자 전망이 자산배분 과정에서 확률을 이용하여 반 영된다는 특성 때문에 하나은행[2], 미래에셋[4], 삼 성증권[6], 동양증권[7], 그리고 우리투자증권[10]과 같은 국내 금융 회사는 블랙리터만 모형을 이용하 여 자산 배분비중을 결정한다. 하나은행은 블랙리터 만 모형을 기반으로 하는 자산배분 시스템을 개발하 여 자산 유형 별 투자 비중을 결정한다. 미래에셋은 투자성향별 자산배분 비중을 결정하는 펀드를 구성 하며, 삼성증권은 글로벌 자산배분 정책에 블랙리터 만 모형을 이용한다. 동양증권은 ETF 투자전략을 위해 블랙리터만 모형을 사용하고 있다. 또한 우리 투자증권은 블랙리터만 모형을 이용하여 금속관련 
투자 자산에 대한 포트폴리오를 구성한다.

블랙리터만 모형은 현업의 금융회사에서 널리 쓰 일 뿐 아니라, 전망행렬 생성이나 투자 전략과 같은 블랙리터만 모형 연구도 활발하다. 전망행렬 생성 을 위한 연구에서 Fabozzi[13]는 블랙리터만 모형에 모멘텀 전략을 적용하여 포트폴리오를 구성하였다. Idzorek[16]는 사용자에 따라 전망에 대한 신뢰도를 다르게 반영하는 방안을 연구하였다. 그리고 Mulvey [20]는 모멘텀을 이용한 전망행렬 생성 방법을 추정 하였다. $\mathrm{He}[15]$ 는 투자자 전망이 추가될 경우, 투자 자 전망의 신뢰성에 근거하여 포트폴리오 구성에 미치는 영향을 분석하였다. 투자 전략에 따른 포트 폴리오 구성 연구에서 Jones et al.[17]는 인핸스드 인덱스 펀드 구성을 위해 투자자 전망 대신 요소 모형(Factor Model)을 개발하여 포트폴리오 노출 정도를 제한하는 틸팅 최적화 모형을 설계하였다. Yanou[25]는 블랙리터만 모형을 기존에 보유한 포 트폴리와 결합하여 샤프비율을 최대화하는 모형을 설계하고, 전망을 반영하여 모형을 설계할 때 기회 비용과 전망 오류에 대한 상충관계를 분석하였다. 또한 Silva[21]는 액티브 포트폴리오를 구성을 위한 블랙리터만 모형을 이용하였다. 이 연구는 액티브 포트폴리오에서 균형기대수익률은 적합하지 않음 을 증명하고 균형기대 수익률을 고려하지 않는 포 트폴리오 최적화 모형을 설계하였다. Kaiser[18]는 인핸스드 포트폴리오 설계를 위해 블랙리터만 모형 을 사용하였고, 전망행렬 구성을 위해 요인 모형 (Factor model)을 이용하며 전망 불확실성 설정을 위해 $R^{2}$ 를 이용하였다. 송정민[5]은 블랙리터만 모 형을 이용한 섹터투자 전략을 개발하였고, 특히 전 문가 평가에 대한 불확실성을 통계적 검증을 이용 하여 전망행렬의 불확실성을 설정하였다. 이 논문 은 블랙리터만 모형을 이용한 인핸스드 인덱스 모 형을 설계한다. 기존 연구와 달리 전망행렬 구성을 위해 그룹 랭킹 개념을 사용한다. 그리고 $\mathrm{ETF}$ 를 목 표지수 추적에 이용하고 액티브 포트폴리오를 통해 목표지수 초과수익률을 추구하는 인핸스드 인덱스 최적화 모형을 개발한다.
이 논문은 다음과 같이 구성된다. 제 2장에서 블 랙리터만 모형를 소개한다. 그리고 제 3장에서는 블랙리터만 모형을 이용한 인핸스드 인덱스 전략 구축 방법을 제시하고, 포트폴리오의 IR을 개선하 는 최적화 모형을 개발한다. 제 4장은 인핸스드 인 덱스 전략에 대한 결과를 제시하고, 끝으로 5 장에 는 결론과 향후 연구 과제를 기술한다.

\section{2. 블랙리터만 모형}

블랙리터만 모형은 시장에 내재된 균형기대수익 률과 투자자 전망을 결합하여 블랙리터만 기대수 익률을 계산한다. 자산의 수가 $n$ 개 일 때, $\lambda$ 는 위 험회피계수 (상수), $\Sigma$ 는 과거수익률 $n \times n$ 공분산행 렬, 그리고 $w_{m k t}$ 는 시장에서 $n \times 1$ 자산의 시가총액 비중 벡터라고 하면, 시장에 내재된 자산의 균형기 대수익률 ( $\Pi, n \times 1$ 벡터)은 식 (1)과 같이 정의한다.

$$
\Pi=\lambda \Sigma w_{m k t}
$$

블랙리터만 모형에서 투자자 전망 반영을 위해 전망행렬을 구성한다. 블랙리터만 모형에서 투자자 의 전망은 식 (2)와 같이 정의한다.

$$
P E(r)=q+\epsilon, \epsilon \sim N(0, \Omega)
$$

식 (2) 에서 $P$ 는 $k \times n$ 투자자 전망 행렬 ( $k$ 는 전망 수, $E(r)$ 은 $n \times 1$ 기대수익률 벡터, $q$ 는 각 전 망에 대한 $k \times 1$ 기대수익률 벡터, $\epsilon$ 는 $k \times 1$ 투자자 전망 오차항벡터, 그리고 $\Omega$ 는 투자 전망 오차항에 대한 $k \times k$ 공분산행렬을 나타낸다.

블랙리터만 기대수익률 계산을 위해 균형기대수 익률과 투자자 전망을 결합한다. 결합 방법은 베이 지안 방법(Bayesian Approach)을 사용하며, 결합계 수 $\tau$ 에 대한 블랙리터만 기대수익률 $\left(\mu_{B L}, n \times 1\right.$ 벡 터)은 식 (3)과 같다[23].

$\mu_{B L}=\left[(\tau \Sigma)^{-1}+P^{T} \Omega^{-1} P\right]^{-1}\left[(\tau \Sigma)^{-1} \Pi+P^{T} \Omega^{-1} q\right]$ 
식 (3)에서 투자자가 전망이 없다면 $q=\Omega=0$ 이고, 블랙리터만 기대수익률은 $\mu_{B L}=\Pi$ 가 되며, 전 망이 없는 경우 투자 비중은 시장 비중과 같다. 또 한 블랙리터만 모형을 변형하면 식 (4)와 같다[23].

$$
\mu_{B L}=\Pi+\tau \Sigma P^{T}\left[\Omega+\tau P \Sigma P^{T}\right]^{-1}[q-P \Pi]
$$

식 (4)에서 블랙리터만 기대수익률은 균형기대 수익률에서 전망행렬을 고려한 틸팅의 의미를 갖 는다. 따라서 블랙리터만 기대수익률을 이용한 자 산 구성은 인핸스드 인덱스의 의미를 갖으므로 인 핸스드 인덱스 펀드 구성을 위해 블랙리터만 포트 폴리오 최적화 모형을 사용한다. 블랙리터만 모형 문제 정의에 필요한 집합, 모수, 그리고 결정변수 는 다음과 같다.

(집합) $N$ : 자산 집합 $N=\{1, \cdots, n\}$

(모수) $\mu_{B L_{i}}$ : 자산 $i \in N$ 의 블랙리터만 기대수익률 $\sigma_{i j}$ : 자산 $i \in N$ 와 자산 $j \in N$ 의 수익률 공분산 $\lambda:$ 위험회피계수

(결정변수) $w_{i}$ : 포트폴리오에서 자산 $i \in N$ 의 비중

블랙리터만 포트폴리오 최적화 모형은 식 (5) 식 (7)과 같다.

$$
\begin{array}{ll}
\text { Maximize } & \sum_{i=1}^{n} \mu_{B L_{i}} w_{i}-\frac{\lambda}{2} \sum_{i=1}^{n} \sum_{j=1}^{n} \sigma_{i j} w_{i} w_{j} \\
\text { Subject to } & \sum_{i=1}^{n} w_{i}=1, \\
& w_{i} \geq 0, \quad i=1,2, \cdots, n .
\end{array}
$$

식 (5)에서 블랙리터만 포트폴리오 최적화 모형 의 목적함수는 평균분산 모형과 동일하며 수익률 을 블랙리터만 기대수익률로 변경한다. 식 (6)는 포 트폴리오를 구성하는 자산 비중의 합이 1 임을 나 타낸다. 식 (7)은 공매도 금지 제약을 나타낸다.

Remark 1 : 블랙리터만 포트폴리오 구성을 위해 블랙리터만 수익률을 이용한 역최적화 방법이 사 용 가능하다[16]. 그러나 역최적화 방법은 전망행 렬 구성에 따라 포트폴리오 비중이 음수가 나와 공 매도를 허용하게 된다. 또한 자산의 총합도 1 을 보
장하지 않는다. 따라서 블랙리터만 포트폴리오 최 적화 모형 (5) 모형 (7)은 공매도를 허용하지 않 는 실제 투자 가능한 대안을 제시한다.

블랙리터만 포트폴리오 모형을 계산해서 얻은 자산 비중은 시장 비중에 대한 자산 전망의 틸팅으로 인핸스 드 인덱스 효과를 갖는다. 하지만, 투자자 전망에 따라 특정 자산에 비중이 집중되어 시장 지수를 추적하는 포트폴리오 구성이 어렵다. 따라서 투자 자산에 시장 지수를 안정적으로 추적하는 ETF를 포함한 인핸스드 인덱스 펀드 구성 방법을 제안한다. ETF를 블랙리터 만 포트폴리오 모형의 자산에 포함할 경우, 다른 자산 에 비해 변동성이 적고 수익률이 높지 않기 때문에 $\mathrm{ETF}$ 가 선택되지 않는 경우가 발생한다. 따라서 ETF 를 블랙리터만 모형과 결합하는 새로운 방법을 제시하 여 시장지수를 효과적으로 추적하며 초과 수익률을 달성하는 인핸스드 인덱스 펀드를 설계한다.

\section{3. 블랙리터만 모형을 이용한 인핸스드 인덱스 전략}

이 논문은 블랙리터만 포트폴리오를 $\mathrm{ETF}$ 와 결합 하여 인핸스드 인덱스 펀드를 설계한다. <그림 3>에 서 인핸스드 인덱스 펀드 설계를 위해 시장에 내재된 균형기대수익률과 투자자 전망을 결합하여 블랙리터 만 포트폴리오를 계산하고, $\mathrm{ETF}$ 와 결합하는 방법을 개발한다. 결합 방법에는 실험 데이터에 ETF 포함, 균형기대 수익률 비율 계산, 불확실성을 이용한 가중 결합, 정보비율(Information Ratio, IR) 최대화 비중 계산, 그리고 $\mathrm{ETF}$ 최대화 모형 개발이 있다.

균형기대수익은 주식 시장에 포함된 모든 자산 으로 계산하지 않고 시장 전체를 대표하는 KOSPI 200 을 이용하며, 위험회피계수 $(\lambda)$ 는 KOSPI 200 의 평균수익률 $\left(E\left(r_{M}\right)\right)$, 무위험 자산 수익률 $\left(r_{f}\right)$, 그리 고 KOSPI200 일일 수익률 분산 $\left(\sigma_{M}^{2}\right)$ 을 이용하여 식 (8)과 같이 계산한다.

$$
\lambda=\left(E\left(r_{M}\right)-r_{f}\right) / \sigma_{M}^{2}
$$




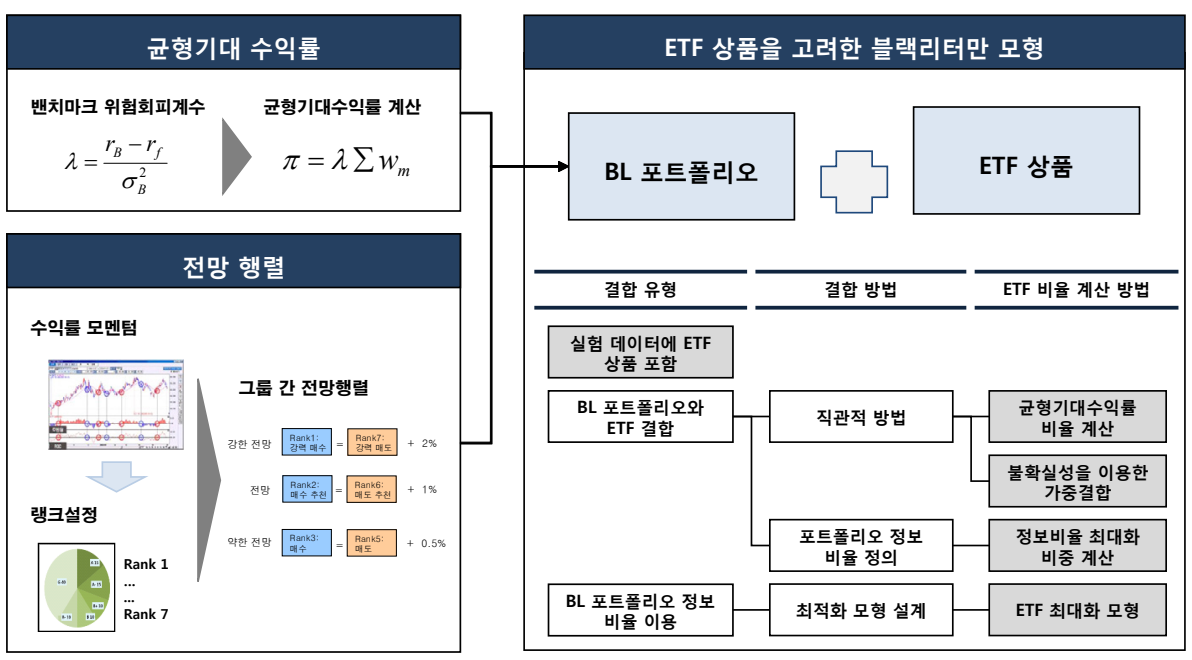

〈그림 3〉 블랙리터만 모형을 이용한 인핸스드 인덱스 전략

전망행렬은 수익률 모멘텀을 이용하여 구성한다. 모멘텀은 주가의 증가 또는 감소 추세를 측정한 지표이 다. $z_{t, i}$ 는 $t$ 시점에서 자산 $i$ 의 모멘텀, $P_{t, i}$ 는 $t$ 시점에서 자산 $i$ 의 가격, $\delta$ 는 모멘텀 산정 기간, 그리고 $\sigma_{i}$ 는 자산 $i$ 의 표준편차일 때, 모멘텀은 식 (9)와 같다[13].

$$
z_{t, i}=\frac{P_{t-1, i}-P_{t-1-\delta, i}}{P_{t-1-\delta, i} \sigma_{i}}
$$

모멘텀은 일정 기간 내 수익률을 자산의 표준편 차로 나눈 값으로, 동일한 위험에 대한 개별 자산 의 수익률을 의미한다. 모멘텀을 이용한 전망행렬 구성을 위해 투자 전망에 따라 7 개의 랭킹 그룹을 생성한다. 낮은 랭크 그룹은 매수 선호 자산이고, 높은 랭크 그룹은 매도 선호 자산이다. 이를 고려 하여 랭킹 그룹 1 은 강력 매수, 랭킹 그룹 2는 매수 추천, 랭킹 그룹 3은 매수, 랭킹 그룹 4는 보유, 랭 킹 그룹 5 는 매도, 랭킹 그룹 6 은 매도 추천, 그리 고 랭킹 그룹 7은 강력 매도로 설정한다. 랭크 정보 를 이용하여 전망 행렬을 생성하기 위해 Mulvey [20]가 제안한 그룹 간 전망 행렬을 사용한다. 그룹 간 전망 행렬은 총 3 개로 구성되며, 랭킹 1 과 랭킹 7 로 구성된 강한 전망, 랭킹 2 와 랭킹 6 으로 구성된 중립 전망, 랭킹 3 과 랭킹 5 로 구성된 약한 전망으
로 설정한다. 각 전망에 대한 전망치는 연 수익률 기준으로 $2.0 \%(=0.167 \% /$ 월 $), 1.0 \%(=0.083 \% /$ 월 $)$, 그리고 $0.5 \%(=0.042 \% /$ 월 $)$ 로 설정한다. 그룹 $i$ 의 자산 집합을 $G_{i}$, 자산 집합에 포함된 자산 수를 $n_{i}$, 그리고 자산 $i$ 의 기대수익률을 $\mu_{i}$ 을 이용한 전망에 대한 관계식은 식 (10) 식 (12)로 나타낸다.

강한 전망 $\quad \frac{1}{n_{1}} \sum_{i \in G_{1}} \mu_{i}=\frac{1}{n_{7}} \sum_{i \in G_{7}} \mu_{i}+2.0 \%$

중립 전망 $\quad \frac{1}{n_{2}} \sum_{i \in G_{2}} \mu_{i}=\frac{1}{n_{6}} \sum_{i \in G_{6}} \mu_{i}+1.0 \%$

약한 전망 $\quad \frac{1}{n_{3}} \sum_{i \in G_{3}} \mu_{i}=\frac{1}{n_{5}} \sum_{i \in G_{5}} \mu_{i}+0.5 \%$

식 (10)은 랭킹 그룹 1 의 기대수익률이 랭킹 그 룹 7 의 기대수익률 보다 $2 \%$ 크다는 것을 의미하 고, 식 (11)은 랭킹 그룹 2가 랭킹 그룹 6보다 기대 수익률이 $1 \%$ 크다는 것을 의미한다. 그리고 식 (12)는 랭킹 그룹 3이 랭킹 그룹 5보다 $0.5 \%$ 기대 수익률이 크다는 것을 의미한다. 이를 바탕으로 식 (2)에서 전망 수 $k$ 는 3 개이며, 전망 기대 수익률 벡터는 $q^{T}=\left[\begin{array}{lll}2 & 1 & 0.5\end{array}\right]$ 이다. 그리고 $3 \times n$ 전망행렬 벡터 $P$ 의 원소는 식 (10) 식 (12)에서 결정되며, 그 값은 식 (13) 식 (14)와 같다. 


$$
\begin{aligned}
& P_{i j}=\frac{1}{n_{i}}, \quad j \in G_{i}, \quad i=1,2,3, \\
& P_{(8-i) j}=-\frac{1}{n_{i}}, \quad j \in G_{i}, \quad i=5,6,7,
\end{aligned}
$$

블랙리터만 기대수익률은 위험조정계수 $(\tau)$ 에 따 라 값의 변화가 크다. 따라서 위험조정계수와 관계 없이 블랙리터만 기대수익률을 계산하기 위해 전 망행렬에 대한 공분산행렬 $(\Omega)$ 을 식 (15)와 같이 정 의한다.

$$
\Omega=\operatorname{diag}\left(\tau P \Sigma P^{\prime}\right)
$$

위에서 제시한 균형기대수익률과 랭킹을 이용한 전망행렬을 결합하여 블랙리터만 수익률을 계산하 고 식 (5) 식 (7)을 이용하여 블랙리터만 포트폴 리오를 구성한다.

한편 $\mathrm{ETF}$ 를 고려한 인핸스드 인덱스 펀드 구성 을 위해서 블랙리터만 포트폴리오와 ETF를 결합한다. $\mathrm{ETF}$ 결합 유형은 실험 데이터에 $\mathrm{ETF}$ 를 포함하는 방법, 블랙리터만 포트폴리오를 구성하고 $\mathrm{ETF}$ 를 결합하는 방법, 그리고 블랙리터만 정보비율을 이 용한 최적화 모형 개발이 있다. ETF는 투자 가능한 자산이므로 다른 투자 자산처럼 실험 데이터에 포 함하여 블랙리터만 모형을 구현한다. 블랙리터만 포트폴리오를 구성한 후 $\mathrm{ETF}$ 를 결합하는 방법은 블랙리터만 포트폴리오에서 각 자산이 차지하는 비 중을 변화시키지 않을 때, ETF 비중에 따른 포트폴 리오의 성과 분석이 가능하다. ETF 비중을 결정하 기 위해 직관적 방법과 포트폴리오 정보 비율을 이 용하는 방법이 있다. 직관적인 방법은 투자자가 비 교적 간단하게 의사결정 할 수 있는 방법으로 블랙 리터만 수익률 중 균형기대수익률이 차지하는 비중 을 $\mathrm{ETF}$ 로 대체하는 균형기대수익률 비율 계산 방 법과 블랙리터만 포트폴리오 분산과 ETF 분산의 가중 결합 방법이 있다. 그러나 직관적인 방법은 포 트폴리오 개선을 위한 지표나 방법론이 포함되어 있지 않기 때문에 포트폴리오 성과에 대한 근거를 명확히 제시하기 어렵다. 따라서 인핸스드 인덱스 를 평가하는 지표인 정보비율을 이용한 $\mathrm{ETF}$ 비중 결정 방법을 제시한다. 정보비율은 포트폴리오의
목표 지수 초과수익률을 초과수익률에 대한 표준편 차로 나눈 값으로, 값이 클수록 단위 리스크에 대한 기대수익률이 크다는 것을 의미한다. 따라서 블랙 리터만 포트폴리오와 $\mathrm{ETF}$ 를 결합한 포트폴리오의 정보비율을 최대화하는 $\mathrm{ETF}$ 비중을 계산한다. 한 편, 블랙리터만 포트폴리오의 정보비율을 이용하여 최적화 모형을 설계한다. 최적화 모형을 이용할 경 우, 기존에 설계한 블랙리터만 포트폴리오의 자산 비중이 모두 변하기 때문에 ETF가 포함된 새로운 포트폴리오 구성이 가능하다. 또한 블랙리터만 포트 폴리오의 정보비율을 개선하면서, $\mathrm{ETF}$ 를 최대화하 는 최적화 모형을 설계하여 목표지수를 초과하면서 초과수익률을 달성하는 인핸스드 인덱스 펀드에 적 합한 포트폴리오를 구성한다.

\section{1 균형기대수익률 비율을 이용한 ETF 결합}

블랙리터만 기대수익률에서 균형기대수익률에 해 당하는 비율을 ETF 비중으로 결정한다. 블랙리터 만 기대수익률 $\left(\mu_{B L}\right)$ 은 식 (16)에서 균형기대수익률 ( $\Pi)$ 과 투자 전망에 의한 수익률 $(V, n \times 1$ 벡터 $)$ 로 나뉜다.

$\mu_{B L}=\Pi+\tau \Sigma P^{T}\left[\Omega+\tau P \Sigma P^{T}\right]^{-1}(q-P \Pi)=\Pi+V$

균형기대수익률은 평균분산 모형에서 자산 시장 비중을 계산한고, 투자 전망에 의한 수익률은 전망에 따른 개별 자산에 조정 정도를 나타낸다. 따라서 균형 기대수익률이 블랙리터만 기대수익률에 기여하는 정 도를 식 (17)과 같이 $\mathrm{ETF}$ 비중 $\left(w_{E T F}\right)$ 으로 결정한다.

$$
w_{E T F}=\left(\Pi \times w_{B L}\right) /\left(\mu_{B L} \times w_{B L}\right)
$$

따라서 새롭게 구성된 인핸스드 인덱스 펀드는 $\mathrm{ETF}$ 비중이 $w_{E T F}$ 이고, 블랙리터만 포트폴리오 비 중이 $1-w_{E T F}$ 이다. $w_{E T F}$ 는 모수에 따라 음수가 나오 는 경우와 1 보다 큰 경우가 존재할 수 있다. 0 보다 작은 경우 $w_{E T F}=0$ 이고, 0 보다 큰 경우 $w_{E T F}=1$ 로 설정한다. 나머지 경우에 $w_{E T F}$ 는 0 에서 1 사이의 값을 갖는다. 


\section{2 분산을 고려한 가중 결합}

$\mathrm{ETF}$ 분산과 블랙리터만 포트폴리오 분산을 가중 결합하여 인핸스드 인덱스 펀드를 구성한다. 분산은 포트폴리오가 지닌 불확실성을 나타내므로, 분산이 작은 포트폴리오에 더 많은 비중을 주고, 분산이 큰 포트폴리오에 적은 비중을 준다. 분산을 고려한 가 중결합방식에 의한 $\mathrm{ETF}$ 비중은 식 (18)과 같다.

$$
w_{E T F}=\left(1 / \sigma_{E T F}^{2}\right) /\left(1 / \sigma_{E T F}^{2}+1 / \sigma_{B L}^{2}\right)
$$

위와 마찬가지로, $\mathrm{ETF}$ 비중을 $w_{E T F}$ 로 블랙리터 만 포트폴리오 비중을 $1-w_{E T F}$ 로 인핸스드 인덱스 펀드를 구성한다.

\section{3 정보비율 최대화 모형}

$\mathrm{ETF}$ 와 블랙리터만 포트폴리오를 결합하여 정보 비율을 최대화하는 인핸스드 인덱스 펀드를 구성 한다. 정보비율은 목표 지수 초과수익률을 표준편 차로 나눈 값이며, $\mathrm{ETF}$ 와 블랙리터만 포트폴리오 를 결합한 인핸스드 인덱스 펀드의 정보비율은 식 (19)와 같다.

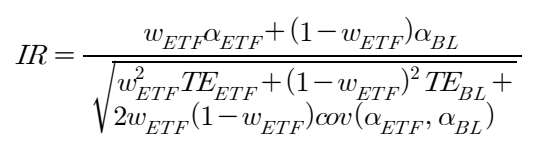

식 (19)에서 $a_{E T F}$ 과 $\alpha_{B L}$ 는 $\mathrm{ETF}$ 와 블랙리터만 포트폴리오의 초과수익률을 나타내고, $T E_{E T F}$ 와 $T E_{B L}$ 은 ETF와 블랙리터만 포트폴리오의 분산이고, $\operatorname{cov}\left(\alpha_{E T F,}, \alpha_{B L}\right)$ 은 공분산이다. 따라서 정보비율을 최 대화하는 $\mathrm{ETF}$ 비중 $\left(w_{E T F}\right)$ 을 계산하여 인핸스드 인 덱스 펀드를 구성한다. $w_{E T F}$ 는 모수 값에 따라 0에서 1 사이 값을 갖는다. 그러나 일반적으로 $\mathrm{ETF}$ 상품은 초과수익률이 크지 않기 때문에 대부분의 경우 $w_{E T F}=0$ 이 된다. 따라서 기존 포트폴리오의 자산 비 중을 변화없이 $\mathrm{ETF}$ 를 결합하여 정보비율을 개선하 기 어렵다. 이러한 정보비율 문제 해결을 위해 인핸 스드 인덱스 펀드 최적화 모형을 제안한다.

\section{4 블랙리터만 포트폴리오의 정보비율을 고 려한 인핸스드 인덱스 펀드 최적화 모형}

인핸스드 인덱스 펀드 구성을 위해 블랙리터만 포트폴리오의 정보비율을 개선하는 최적화 모형을 개발한다. 최적화 모형에서 목적식은 $\mathrm{ETF}$ 비중 최 대화이고, 제약식은 비중 제약과 정보비율 제약이다. 최적화 모형 설계를 위한 집합, 모수, 그리고 결정 변수는 다음과 같다.

(집합) $N: \mathrm{ETF}$ 를 제외한 투자 자산의 집합

(모수) $\alpha_{E T F}$ : 목표지수 대비 $\mathrm{ETF}$ 의 초과수익률 $\alpha_{i}$ : 목표지수 대비 자산 $i \in N$ 의 초과수익률 $\alpha_{B L}$ : 목표지수 대비 블랙리터만 포트폴리 오의 초과수익률

$T E_{E T F, i}: \mathrm{ETF}$ 와 자산 $i \in N$ 의 목표지수 초 과수익률에 대한 공분산

$T E_{i, j}$ : 자산 $i \in N$ 와 자산 $j \in N$ 의 목표지수 초과수익률에 대한 공분산

$T E_{B L}^{2}$ : 블랙리터만 포트폴리오의 목표지 수 초과수익률에 대한 분산

$I R_{B L}$ : 블랙리터만 포트폴리오의 정보비율

(결정변수) $w_{E T F}$ : 포트폴리오에서 $\mathrm{ETF}$ 비중 $w_{i}$ : 포트폴리오에서 자산 $i \in N$ 비중

블랙리터만 포트폴리오 정보비율을 고려한 ETF 최대화 모형은 식 (20) 식 (22)와 같다.

$$
\begin{array}{ll}
\text { Maximize } & w_{E T F} \\
\text { Subject to } & w_{E T F}+\sum_{i=1}^{n} w_{i}=1 \\
& \frac{\alpha_{E T F} w_{E T F}+\sum_{i=1}^{n} \alpha_{i} w_{i}}{\sqrt{\sum_{i=1}^{n} T E_{E T F, i} w_{i} w_{E T F}+}} \geq I R_{B L}, \\
& \sqrt{\sum_{i=1}^{n} \sum_{j=1}^{n} T E_{i j} w_{i} w_{j}} \\
& w_{i} \geq 0, \quad i=1,2, \cdots, n, \\
& w_{E T F} \geq 0 .
\end{array}
$$

목적함수 (20)은 ETF 최대 비중을 나태내고, ETF 비중이 클수록 목표 지수 추적 수준이 높다. ETF 비 
중이 커질수록 목표지수와 유사하여 정보비율이 0 이 된다. 그러나 정보비율 제약으로 $\mathrm{ETF}$ 비중은 1 이 되기 어렵다. 식 (21)은 투자 자산 비중이 1임을 나타낸다. 식 (22)는 포트폴리오 정보비율이 블랙리 터만 정보비율보다 높음을 나타낸다. 위의 모형에 서 정보 비율 개선을 위해 초과수익 부분과 추적오 차 부분을 나누어 변형된 모형을 만든다. 정보비율 을 분리한 인핸스드 인덱스 최적화 모형은 식 (23) 식 (24)와 같다.

$$
\begin{array}{ll}
\text { Maximize } & w_{E T F} \\
\text { Subject to } & w_{E T F}+\sum_{i=1}^{n} w_{i}=1 \\
& \alpha_{E T F} w_{E T F}+\sum_{i=1}^{n} \alpha_{i} w_{i} \geq \alpha_{B L} \\
& \sum_{i=1}^{n} T E_{E T F, i} w_{i} w_{E T F} \\
& +\sum_{i=1}^{n} \sum_{j=1}^{n} T E_{i j} w_{i} w_{j} \leq T E_{B L}^{2} \\
& w_{i} \geq 0, \quad i=1,2, \cdots, n, \\
& w_{E T F} \geq 0 .
\end{array}
$$

식 (23)는 포트폴리오 초과수익률이 블랙리터만 포트폴리오의 초과수익률보다 높음을 나타내고, 식 (26)은 추적 오차가 블랙리터만 포트폴리오보다 낮 음을 나타낸다. 따라서 기존 블랙리터만 포트폴리오 보다 높은 초과수익률과 적은 추적오차를 갖도록 한다.

\section{4. 실험 결과}

인핸스드 인덱스 펀드 최적화 모형을 실험하기 위하여 <표 1 >과 같은 KOSPI200 주식 데이터를 사용한다. 시가 총액이 크기순으로 주식 29개를 선 정하고 $\mathrm{ETF}$ 상품으로 KODEX200를 이용한다.

데이터수집 기간은 2011년 10월 1일부터 2013년 3 월 31일이며, 데이터는 <표 2>와 같이 내표본(Insample) 데이터와 외표본(Out-sample) 데이터로 분 류된다. 내표본 데이터는 모수 추정에 사용되고, 외 표본 데이터는 모형 검증에 사용된다. 내표본 데이 터는 외표본 실험 데이터 시작 3 개월, 6 개월, 9 개월, 그리고 12 개월 전 주식 데이터를 이용한다. <그림 $4>$ 는 데이터 수집 기간 내 KOSPI200 지수 변화를 나타내며, 기간 내 주식 변화는 상승기, 횡보기, 하 락기가 불규칙하게 진행되기 때문에, 인핸스드 인 덱스 모형의 강건성을 증명하기에 적합하다. 모형 사 용을 위한 위험회피계수 $(\lambda)$ 과 전망값을 설정한다. 블랙리터만 수익률 계산을 위한 위험 회피 계수는 2012년 10월 1일부터 2013년 3월 31일까지 KOSPI

\begin{tabular}{|c|c|c|c|c|c|c|c|c|c|}
\hline 주식이름 & 시가총액 & 주식이름 & 시가총액 & 주식이름 & 시가총액 & 주식이름 & 시가총액 & 주식이름 & 시가총액 \\
\hline 삼성전자 & $\begin{array}{l}222,864 \\
(33.7 \%)\end{array}$ & $\begin{array}{c}\mathrm{SK} \\
\text { 하이닉스 }\end{array}$ & $\begin{array}{l}19,784 \\
(3.0 \%)\end{array}$ & $\begin{array}{c}\text { SK } \\
\text { 이노베이션 }\end{array}$ & $\begin{array}{l}14,332 \\
(2.2 \%)\end{array}$ & LG & $\begin{array}{l}10,750 \\
(1.6 \%)\end{array}$ & KT & $\begin{array}{c}9,283 \\
(1.4 \%)\end{array}$ \\
\hline 현대차 & $\begin{array}{l}46,258 \\
(7.0 \%)\end{array}$ & 한국전력 & $\begin{array}{l}19,676 \\
(3.0 \%)\end{array}$ & $\mathrm{KB}$ 금융 & $\begin{array}{l}14,314 \\
(2.2 \%)\end{array}$ & 삼성물산 & $\begin{array}{l}10,560 \\
(1.6 \%)\end{array}$ & $\begin{array}{c}\mathrm{LG} \\
\text { 생활건강 }\end{array}$ & $\begin{array}{c}9,121 \\
(1.4 \%)\end{array}$ \\
\hline $\begin{array}{l}\text { 현대 } \\
\text { 모비스 }\end{array}$ & $\begin{array}{l}29,885 \\
(4.5 \%)\end{array}$ & 신한지주 & $\begin{array}{l}18,897 \\
(2.9 \%)\end{array}$ & $\mathrm{NHN}$ & $\begin{array}{l}13,789 \\
(2.1 \%)\end{array}$ & KT\&G & $\begin{array}{l}10,366 \\
(1.6 \%)\end{array}$ & $\begin{array}{c}\text { 하나 } \\
\text { 금융지주 }\end{array}$ & $\begin{array}{c}9,090 \\
(1.4 \%)\end{array}$ \\
\hline POSCO & $\begin{array}{l}27,900 \\
(4.2 \%)\end{array}$ & $\mathrm{LG}$ 화학 & $\begin{array}{l}16,402 \\
(2.5 \%)\end{array}$ & LG전자 & $\begin{array}{l}12,994 \\
(2.0 \%)\end{array}$ & S-Oil & $\begin{array}{l}10,211 \\
(1.5 \%)\end{array}$ & $\begin{array}{l}\text { 삼성 } \\
\text { 중공업 }\end{array}$ & $\begin{array}{c}7,688 \\
(1.2 \%)\end{array}$ \\
\hline 기아차 & $\begin{array}{l}21,565 \\
(3.3 \%)\end{array}$ & $\begin{array}{l}\text { 현대 } \\
\text { 중공업 }\end{array}$ & $\begin{array}{l}15,276 \\
(2.3 \%)\end{array}$ & 롯데쇼핑 & $\begin{array}{l}12,675 \\
(1.9 \%)\end{array}$ & 삼성화재 & $\begin{array}{l}10,162 \\
(1.5 \%)\end{array}$ & SK & $\begin{array}{c}7,631 \\
(1.2 \%)\end{array}$ \\
\hline 삼성생명 & $\begin{array}{l}20,500 \\
(3.1 \%)\end{array}$ & $\begin{array}{l}\text { SK } \\
\text { 텔레콤 }\end{array}$ & $\begin{array}{l}14,898 \\
(2.3 \%)\end{array}$ & $\begin{array}{c}\mathrm{LG} \\
\text { 디스플레이 }\end{array}$ & $\begin{array}{l}11,164 \\
(1.7 \%)\end{array}$ & 우리금융 & $\begin{array}{c}9,712 \\
(1.5 \%)\end{array}$ & $\begin{array}{c}\text { KODEX } \\
200\end{array}$ & $\begin{array}{c}4,304 \\
(0.7 \%)\end{array}$ \\
\hline
\end{tabular}
200 의 평균수익률과 무위험 자산 수익률 연 $4 \%=$ $0.0160 \%, 1$ 년 250일 기준)를 이용하며, 계산 값은 3.5658 이다. 모멘텀에 의한 전망값은 데이터 기간 에 맞춰 월별 수익률을 사용한다.

\section{〈표 1〉실험에 사용된 주식과 시가총액과 비중(\%)}

(단위 : 십억 원, 2013년 3월 31일 기준) 
〈표 2〉KOSIP200 실험데이터 기간

\begin{tabular}{|c|c|c|}
\hline Set & 내표본(In-sample) & 외표본(Out-sample) \\
\hline 1 & \multirow{6}{*}{ Out-Sample 시작일 이전 3, 6, 9, 12 개월 } & 2013년 03월 01일 2013년 03월 31일 \\
\hline 2 & & 2013년 02월 01일 2013년 02월 28일 \\
\hline 3 & & 2013년 01월 01일 2013년 01월 31일 \\
\hline 4 & & 2012년 12월 01일 2013년 12월 31일 \\
\hline 5 & & 2012년 11월 01일 2013년 11월 30일 \\
\hline 6 & & 2012년 10월 01일 2012년 10월 31일 \\
\hline
\end{tabular}

실험 방법은 $\mathrm{ETF}$ 를 고려한 인핸스드 인덱스 펀 드(Enhanced Index Fund, EIF) 6개를 비교한다. 인핸스드 인덱스 펀드 6 개는 다음과 같다.

$\mathrm{EIF1}$ : 블랙리터만 모형을 이용하여 구성한 펀드 $\mathrm{EIF} 2$ : 균형기대수익률 비율을 $\mathrm{ETF}$ 로 대체한 펀드 $\mathrm{EIF} 3: \mathrm{ETF}$ 와 블랙리터만 포트폴리오를 가중 결 합한 펀드

$\mathrm{EIF} 4: \mathrm{ETF}$ 와 블랙리터만 포트폴리오를 결합한 포트폴리오의 정보비율을 최대화한 펀드

EIF5 : 인핸스드 인덱스 최적화 모형 1을 이용하여 구성한 펀드

EIF6 : 인핸스드 인덱스 최적화 모형 2를 이용하여 구성한 펀드

포트폴리오 성과 비교를 위해 일일수익률의 베
타, 알파, 초과수익률 평균, 정보비율, 그리고 평균 수익, 표준편차을 이용한다. KOSPI200 수익률과 포트폴리오 수익률을 선형 회귀 분석할 때, 기울기 는 베타이고, 절편은 알파이다. 베타는 시장 지수 에 대한 민감도를 나타내고, 알파는 KOSPI200 수 익에 대한 초과수익률을 나타낸다. 초과수익률 평 균은 KOSPI200 일일 수익률과 포트폴리오 일일 수 익률 차이의 평균이다. 정보 비율(Information Ratio, IR)은 추적오차에 대한 초과수익 비율이며, 초과수익 률 평균을 초과수익률 분산으로 나누어 계산한다. $\mathrm{KOPI} 200$ 의 베타는 1 이며, 알파, 초과수익률 평균, 정보비율은 0이다. 논문에서 $\mathrm{EIF} 1$ 은 CPLEX 12.4 를 이용하여 풀었고, EIF2에서 EIF6은 Microsoft Office Excel 2010을 이용하여 구현하였다. 모든 실 험은 Intel(R) Core(TM) i7-2600 CPU 3.40GHz, $4 \mathrm{~GB} \mathrm{PC}$ 에서 구현되었다.

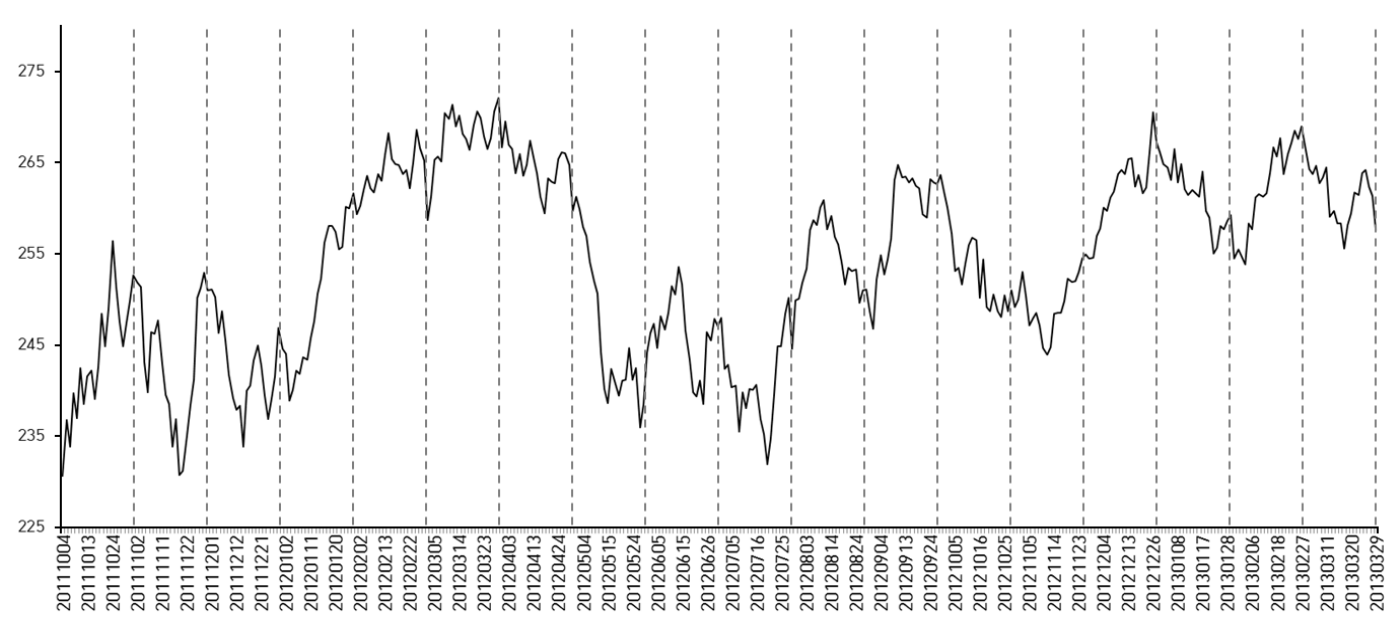


〈표 3〉 내표본 기간 3개월에 대한 포트폴리오 성과

\begin{tabular}{|c|c|c|c|c|c|c|c|c|}
\hline 외표본 & 포트폴리오 & ETF 비중 & 베타 & 알파 & 초과수익률 평균 & 정보비율 & 평균 수익 & 표준편차 \\
\hline \multirow{6}{*}{1} & EIF1 & 0.0000 & 1.3098 & "-0.0012 & 0.0002 & "0.0130 & -0.0015 & (20.0130 \\
\hline & EIF2 & 0.1831 & 1.2503 & -0.0010 & 0.0004 & 0.0237 & -0.0014 & 0.0116 \\
\hline & EIF3 & 0.7628 & 1.0618 & -0.0006 & 0.0008 & 0.0700 & -0.0009 & 0.0080 \\
\hline & EIF4 & 0.0000 & 1.3098 & -0.0012 & 0.0002 & 0.0130 & -0.0015 & 0.0130 \\
\hline & EIF5 & 0.4230 & 1.1671 & -0.0002 & 0.0012 & 0.0951 & -0.0005 & 0.0097 \\
\hline & EIF6 & 0.2967 & 1.2431 & -0.0003 & 0.0011 & 0.0683 & -0.0007 & 0.0125 \\
\hline \multirow{6}{*}{2} & EIF1 & 0.0000 & 1.3422 & -0.0012 & -0.0014 & -0.0835 & 0.0010 & 0.0128 \\
\hline & EIF2 & 0.2176 & 1.2389 & -0.0008 & -0.0012 & -0.0760 & 0.0012 & 0.0115 \\
\hline & EIF3 & 0.7068 & 1.0067 & 0.0001 & -0.0007 & -0.0529 & 0.0016 & 0.0087 \\
\hline & EIF4 & 0.0000 & 1.3422 & -0.0012 & -0.0014 & -0.0835 & 0.0010 & 0.0128 \\
\hline & EIF5 & 0.3695 & 1.2102 & -0.0004 & -0.0009 & -0.0551 & 0.0015 & 0.0130 \\
\hline & EIF6 & 0.3262 & 1.3128 & -0.0004 & -0.0007 & -0.0366 & 0.0017 & 0.0159 \\
\hline \multirow{6}{*}{3} & EIF1 & 0.0000 & 1.1438 & -0.0017 & 0.0001 & 0.0089 & -0.0017 & 0.0121 \\
\hline & EIF2 & 0.3438 & 1.0794 & -0.0014 & 0.0004 & 0.0292 & -0.0014 & 0.0105 \\
\hline & EIF3 & 0.6898 & 1.0146 & -0.0012 & 0.0007 & 0.0515 & -0.0011 & 0.0093 \\
\hline & EIF4 & 0.0000 & 1.1438 & -0.0017 & 0.0001 & 0.0089 & -0.0017 & 0.0121 \\
\hline & EIF5 & 0.4196 & 0.8462 & -0.0009 & 0.0010 & 0.0628 & -0.0008 & 0.0114 \\
\hline & EIF6 & 0.3526 & 0.7705 & -0.0009 & 0.0009 & 0.0498 & -0.0009 & 0.0128 \\
\hline \multirow{6}{*}{4} & EIF1 & 0.0000 & 0.3611 & 0.3611 & -0.0019 & -0.1423 & 0.0001 & 0.0074 \\
\hline & EIF2 & 0.3924 & 0.6210 & 0.6210 & -0.0011 & -0.0955 & 0.0009 & 0.0051 \\
\hline & EIF3 & 0.6002 & 0.7586 & 0.7586 & -0.0007 & -0.0622 & 0.0013 & 0.0045 \\
\hline & EIF4 & 0.0000 & 0.3611 & 0.3611 & -0.0019 & -0.1423 & 0.0001 & 0.0074 \\
\hline & EIF5 & 0.5171 & 1.0032 & 1.0032 & -0.0033 & -0.2167 & -0.0013 & 0.0108 \\
\hline & EIF6 & 0.5010 & 1.0166 & 1.0166 & -0.0028 & -0.1960 & -0.0009 & 0.0098 \\
\hline \multirow{6}{*}{5} & EIF1 & 0.0000 & 0.3292 & 0.0002 & -0.0009 & -0.0739 & 0.0004 & 0.0104 \\
\hline & EIF2 & 0.4366 & 0.5940 & 0.0003 & -0.0007 & -0.0796 & 0.0005 & 0.0070 \\
\hline & EIF3 & 0.6116 & 0.7001 & 0.0003 & -0.0007 & -0.0786 & 0.0006 & 0.0064 \\
\hline & EIF4 & 0.0000 & 0.3292 & 0.0002 & -0.0009 & -0.0739 & 0.0004 & 0.0104 \\
\hline & EIF5 & 0.2851 & 0.8611 & 0.0012 & 0.0004 & 0.0280 & 0.0017 & 0.0107 \\
\hline & EIF6 & 0.2850 & 0.8656 & 0.0012 & 0.0004 & 0.0284 & 0.0017 & 0.0108 \\
\hline \multirow{6}{*}{6} & EIF1 & 0.0000 & 0.5865 & 0.0012 & 0.0022 & 0.1394 & 0.0000 & 0.0086 \\
\hline & EIF2 & 0.4989 & 0.7419 & 0.0004 & 0.0010 & 0.0641 & -0.0012 & 0.0078 \\
\hline & EIF3 & 0.5617 & 0.7614 & 0.0003 & 0.0008 & 0.0543 & -0.0013 & 0.0078 \\
\hline & EIF4 & 0.0000 & 0.5865 & 0.0012 & 0.0022 & 0.1394 & 0.0000 & 0.0086 \\
\hline & EIF5 & 0.5132 & 1.0102 & 0.0026 & 0.0027 & 0.1665 & 0.0005 & 0.0124 \\
\hline & EIF6 & 0.4998 & 0.9296 & 0.0023 & 0.0026 & 0.1669 & 0.0004 & 0.0106 \\
\hline
\end{tabular}

<표 3>은 내표본 기간 3개월에 대한 포트폴리오 성과를 나타낸다. ETF는 다른 주식에 비해 수익률 이 높지 않기 때문에 최적화 모형에서 $\mathrm{EIF} 1$ 과 $\mathrm{EIF} 4$ 에서 $\mathrm{ETF}$ 비중이 0이며, $\mathrm{EIF} 2, \mathrm{EIF} 3, \mathrm{EIF}$, 그리고 $\mathrm{EIF} 6$ 은 0보다 큰 $\mathrm{ETF}$ 비중을 갖는다. $\mathrm{EIF} 4$ 는 $\mathrm{EIF} 1$
과 동일한 포트폴리오로 구성되며, 이는 KOSPI200 에 대한 ETF 초과수익률이 0에 가까워 정보비율 개 선이 어렵기 때문이다. EIF2에서 ETF 비중은 블랙 리터만 수익률에서 균형기대수익률이 차지하는 비 중으로 $18.31 \%$ 에서 $49.89 \%$ 의 비중을 갖고, $\mathrm{EIF} 3$ 은 
$56.17 \%$ 에서 $76.28 \%$ 의 ETF 비중을 갖는다. ETF 비 중 증가로 인해 베타는 1에 가까워지며, $\mathrm{ETF} 2$ 와 $\mathrm{ETF} 3$ 이 ETF1보다 KOSPI200 추적 효과가 우수함 을 나타낸다. 또한 EIF2와 EIF3은 외표본 1에서 외 표본 5까지 $\mathrm{EIF} 1$ 보다 알파와 초과수익률 평균이 개 선된다. 정보비율은 외표본 1에서 외표본 4까지 EIF2 와 $\mathrm{EIF} 3$ 이 $\mathrm{EIF} 1$ 보다 우수한 성과를 나타낸다. 평균 수익도 외표본 6을 제외하고 $\mathrm{EIF} 1$ 보다 개선된 성과 를 보이며, 표준편차는 $\mathrm{EIF} 1$ 보다 항상 작다. $\mathrm{EIF} 2$ 와 $\mathrm{EIF} 3$ 의 경우에서 포트폴리오를 구성할 때 $\mathrm{ETF}$ 를 포함할 경우, 블랙리터만 포트폴리오 성과가 개선됨 을 보인다. EIF5와 EIF6은 최적화 모형을 이용하여 포트폴리오를 구성한 경우이며, $\mathrm{EIF} 2$ 와 $\mathrm{EIF} 3$ 과 달리

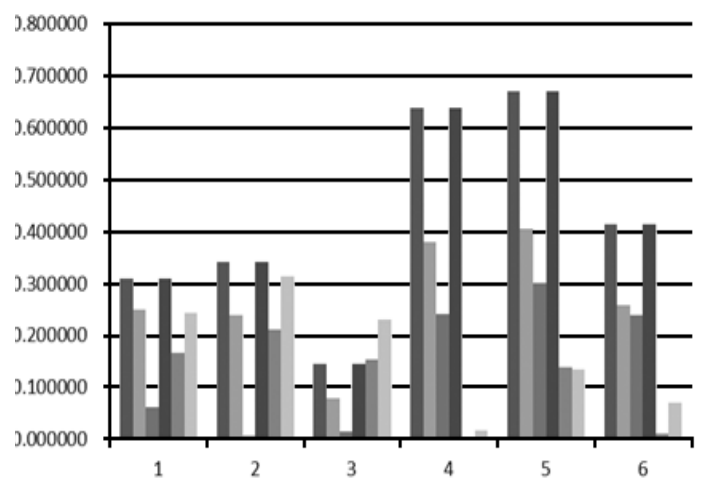

口EIF1 EIF2 EIF3

〈그림 5〉(a) 내표본 3개월의 |베타-1|

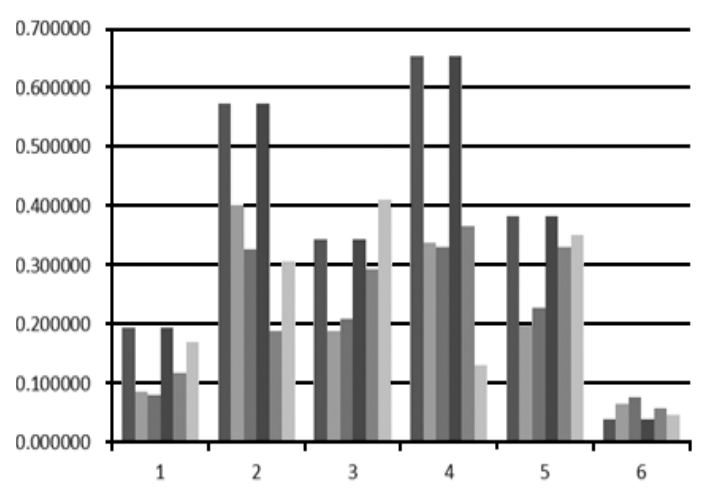

$\square$ EIF1 EIF2 EIF3

〈그림 5〉(c) 내표본 9개월의 |베타-1|
다른 주식에 대한 비중도 변경된 포트폴리오이다. 내표본 기간 3개월 간 $\mathrm{EIF5}$ 와 $\mathrm{EIF6}$ 은 외표본 3의 경 우를 제외하고 베타가 1 에 가까워지며, 알파는 EIF1 보다 항상 우수한 성과를 나타낸다. 초과수익률 평 균과 정보비율은 외표본 4 를 제외하고 $\mathrm{EIF} 1$ 보다 나 은 성과를 낸다. 평균수익에서도 외표본 4 를 제외하 고 우수한 성과를 내며, 표준편차는 외표본 1 과 외표 본 3의 경우를 제외하고 $\mathrm{EIF} 1$ 보다 작아진다. 이는 논 문에서 개발한 포트폴리오 최적화 모형이 기존 블랙 리터만 모형보다 우수한 성과를 보임을 나타낸다.

$<$ 그림 5>는 내표본 데이터 기간에 따른 외표본 데이터 6개에 대한 포트폴리오의 |베타-1|을 나타내며, <그림 6>은 정보비율을 나타낸다. 베타는 1 에 가까

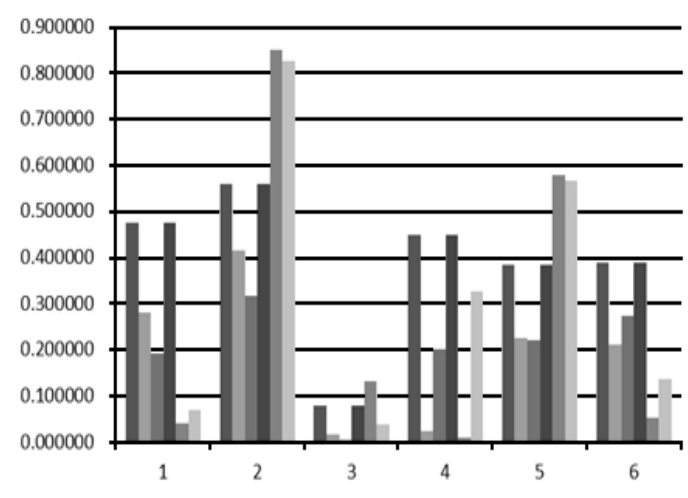

EIF4 EIF5 EIF6

〈그림 5〉(b) 내표본 6개월의 |베타-1|

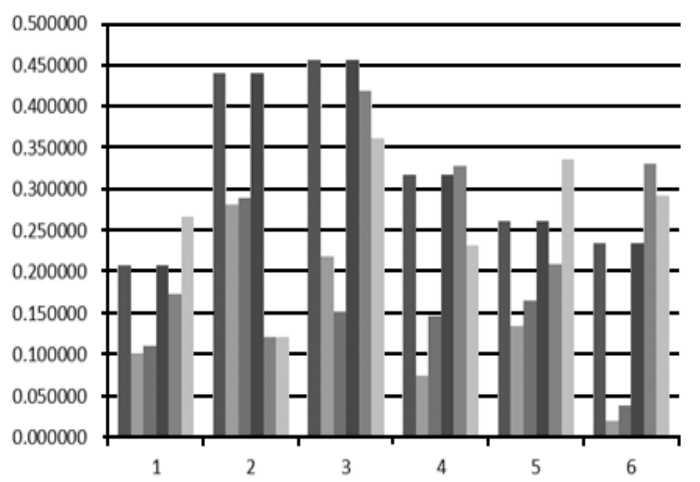

EIF4 EIF5 EIF6

〈그림 5〉(d) 내표본 12개월의 |베타-1| 
울수록 인덱스 추적이 우수함을 나타내기 때문에 차이의 절대값을 이용하여 성과를 분석한다. EIF2 와 $\mathrm{EIF} 3$ 은 $\mathrm{EIF} 1$ 에서 $\mathrm{ETF}$ 비중이 일정 비율로 증가 하였기 때문에 모든 실험 데이터 기간에서 베타값 이 개선된다. 그러나 $\mathrm{EIF} 1$ 에서 선정된 주식과 비중 이 변하는 EIF5와 EIF6의 경우, 내표본 3개월에서 베타 값이 개선된다. EIF5은 내표본 6개월에서 외표 본 6개 중 3 개에서 베타값이 개선되며, EIF6은 내표 본 12 개월에서 외표본 6 개중 3 개에서 베타값이 개 선된다. 이는 EIF5와 EIF6의 초과수익률과 추적오 차는 6 개월 이상의 내표본에서 $\mathrm{EIF} 1$ 과 비슷한 수준 임을 나타낸다. 정보비율의 경우, 내표본 3 개월의 정보비율을 제외하고, 내표본 6개월, 내표본 9개월,

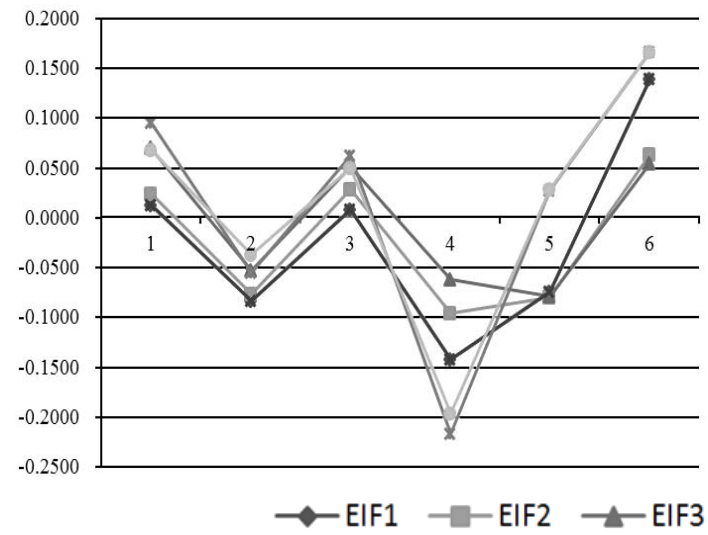

〈그림 6〉(a) 내표본 3개월의 정보비율

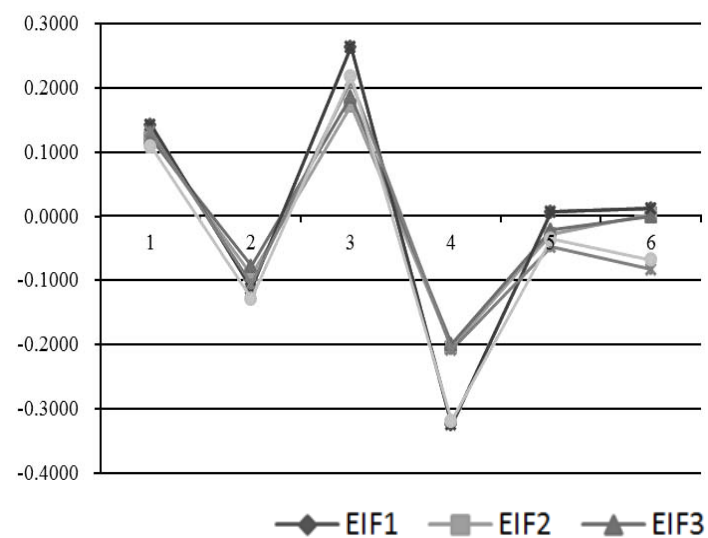

〈그림 6〉(c) 내표본 9개월의 정보비율
그리고 내표본 12 개월에서 EIF2, EIF4, EIF5, 그리고 $\mathrm{EIF6}$ 의 정보비율이 EIF1보다 우수하지 않다. EIF5 는 내표본 6개월에서 항상 $\mathrm{EIF} 1$ 보다 정보비율이 낮 으며, 내표본 9 개월에서 4 회, 그리고 12 개월에서 3 회 정보비율이 낮다. EIF6은 내표본 6개월에서 5회, 9 개월에서 5 회, 12 개월에서 4 회 $\mathrm{EIF} 1$ 보다 낮은 정보 비율을 나타낸다. 이와 같은 결과는 EIF5와 EIF6 모 형에 주식 선정을 위한 초과수익률을 사용할 때 일 일 초과수익률의 평균을 이용하기 때문이다. 6 개월 이상 장기간에 대한 초과수익률 평균은 포트폴리오 수익률에 대한 추세나 투자자 전망을 반영하기 불 충분하기 때문에, 우수한 포트폴리오 성과를 기대하 기 어렵다.

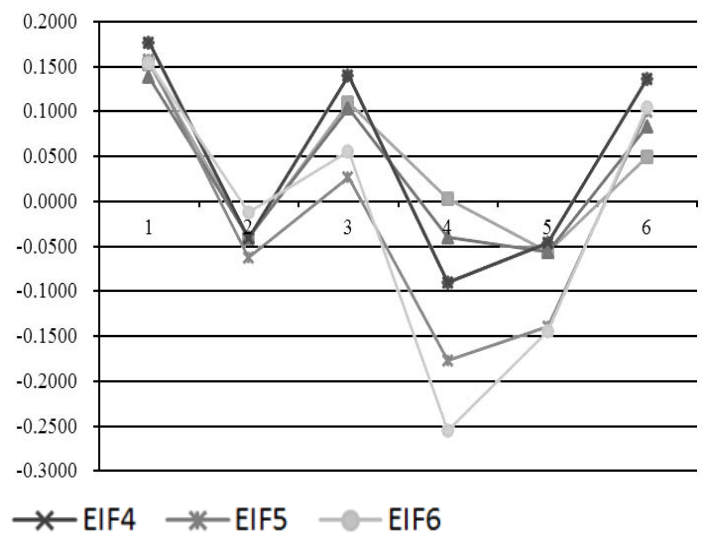

〈그림 6〉(b). 내표본 6 개월의 정보비율

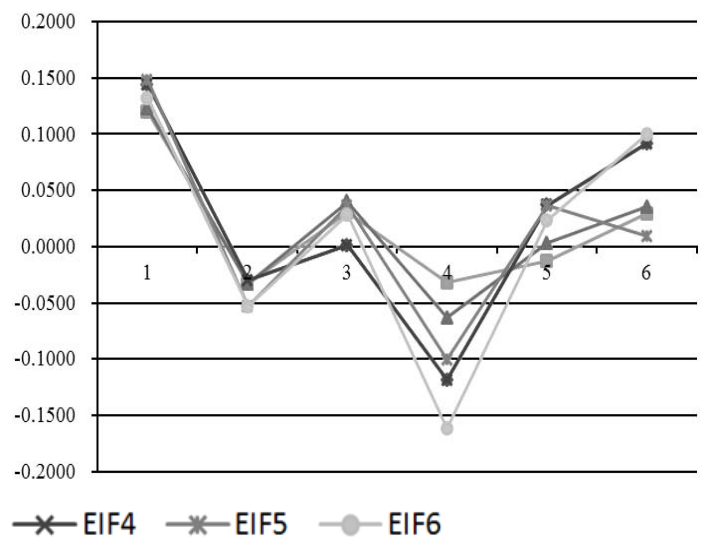

〈그림 6〉(d) 내표본 12개월의 정보비율 


\section{5. 결론 및 향후 과제}

이 논문은 블랙리터만 모형과 ETF를 이용하여 인핸스드 인덱스 펀드를 구성하는 방법을 제시한 다. 블랙리터만 모형은 시장에 내재된 균형기대수 익률을 계산하고 투자자 전망을 결합한 블랙리터 만 기대수익률로 포트폴리오를 구성하는 방법이 다. 블랙리터만 포트폴리오 구성을 위해 목표지수 를 이용하여 위험 회피 계수를 계산하고, 균형기 대수익률을 계산한다. 그리고 투자자 전망 구성을 위해 모멘텀에 근거한 랭킹을 사용하여 그룹 간 전망행렬을 생성한다. 블랙리터만 포트폴리오를 구성한 후 $\mathrm{ETF}$ 와 결합하고, $\mathrm{ETF}$ 결합을 위해 균 형기대수익률 비율, 가중 결합, 정보 비율 최대화, 그리고 블랙리터만 정보비율을 개선하는 최적화 모형을 제시한다. ETF 결합 방식에 대한 포트폴 리오 성과는 내표본 기간 3 개월에 대해서 성과를 비교할 경우 베타, 알파, 초과수익률 평균, 정보 비율, 평균수익, 표준편차 측면에서 기존 블랙리 터만 모형보다 우수한 성과를 내며, 6 개월 이상의 장기간에 대해선 블랙리터만 모형과 비슷한 수준 의 성과를 기록한다. $\mathrm{ETF}$ 는 베타가 1 에 근접하기 때문에 포트폴리오와 결합할 경우 인덱스 추적을 개선한다. 이에 따라 주식시장에서 주식 변동에 대한 위험을 크게 감소시킬 수 있다. 그리고 블랙 리터만 모형의 정보비율을 개선한 최적화 모형은 단기간 내표본에 대해 블랙리터만보다 우수한 성 과를 얻었고, 장기간 내표본에 대해 유사한 성과 를 얻었다. 이는 ETF 결합을 이용한 포트폴리오 구성이 블랙리터만 보다 안정적인 자산 운용이 가능함을 의미한다.

추후 연구 과제로 인핸스드 인덱스 펀드 구성을 위한 전망 행렬 생성 방안을 연구한다. 블랙리터만 모형은 전망행렬 구성 방법에 따라 성과가 크게 달 라지기 때문에 주식 시장의 정보를 효과적으로 반 영할 수 있는 방안 개발이 필요하다. 그리고 블랙 리터만 모형의 한계인 모수 설정에 대한 연구가 필 요하다.

\section{참 고 문 헌}

[1] 곽재혁, "국내 액티브펀드와 인덱스펀드 현황”, 미래에셋자산운용 투자가이드, 2009.

[2] 김대열, 임세찬, 서경덕, "하나-스마트자산배분 전략”, 「하나 Wealth Care」, 제3월(2011), pp.124.

[3] 김휘곤, 이동수, 박현철, "인덱스 펀드의 개념 및 운용현황”, 「한국펀드평가 펀드리서치 월별 보고서」, 제1월(2006), pp.1-37.

[4] 미래에셋 자산운용 컨설팅 본부 자산운용리서 치팀, “연말연초를 대비한 자산배분전략", 「미 래에셋 자산배분전략」, 제12월(2010), pp.2-5.

[5] 송정민, 이영호, 박기경, “블랙리터만 모형을 이용한 섹터지수 투자 전략", 「경영과학」, 제28권, 제1호(2012), pp.57-71.

[6] 신상근, 김유성, 남도현, "한국에 의한, 한국을 위한 글로벌 자산배분”, 「삼성증권 자산배분 전략 보고서」, 제7월(2007).

[7] 이중호, 윤선일, "ETF 자산배분전략 앞에 당 당히 서다”, 「동양종합금융증권 리서치 센터」, 제11월(2011).

[8] 윤재숙, "2012-12월호 KRX ETF Monthly", 「한국거래소 유가증권시장본부 증권상품시장부」, 제18호(2012).

[9] 인덱스 펀드, http://www.indexfund.co.kr.

[10] 최창규, "블랙리터만 모델을 이용한 Metal 자 산 배분”, 「우리투자증권 Derivatives Weekly」, 제5월(2011).

[11] Black, F. and R. Litterman, "Global Asset Allocation with Equities, Bonds, and Currencies," Fixed Income Research, Goldman, Sachs and Company, 1991.

[12] Black, F. and R. Litterman, "Global Portfolio Optimization," Financial Analysts Journal, Vol. 25, No.5(1992), pp.28-43.

[13] Fabozzi, F.J., S.M. Focardi, and P.N. Kolm, "Incorporating Trading Strategies in the Black- 
Litter-man framework," The Journal of Trading, Vol.1, No.2(2006), pp.28-37.

[14] Financial Factory, Available at http://www. financialfactory.com/ranking.asp.

[15] He, G. and R. Litterman, The Intuition behind the Black-Litterman Model Portfolios, Available at SSRN : http://ssrn.com/abstract=334304 or doi:10.2139/ssrn.334304, 2002.

[16] Idzorek, T.M., "A Step-by-Step Guide to the Black-Litterman Model : Incorporating UserSpecified Confidence Levels," Zephyr Associates working paper, 2004.

[17] Jones, R., T. Lim, and P.J. Zangari, "The BlackLitterman Model for Structured Equity Portfolios," The Journal of Portfolio Management, Vol.33, No.2(2007), pp.24-33.

[18] Kaiser, L., A. Veress, and M.J. Menichetti, "Enhanced Optimal Portfolios-A Controlled Integration of Quantitative Predictors," (February 24, 2012), 25th Australasian Finance and Banking Conference 2012, Available at SSRN : http:// ssrn.com/abstract=2010837 or http://dx.doi.org/ 10.2139/ssrn.2010837.
[19] Markowitz, H., "Portfolio Selection," The Journal of Finance, Vol.7, No.1(1952), pp.77-91.

[20] Mulvey, J.M., W.C. Kim, and M. Bilgili, "Linking Momentum Strategies with Single-Period Portfolio Models, or Active Portfolio Management," Handbook of Portfolio Construction, 2010.

[21] Silva, A.S., W. Lee, and B. Pornrojnangkool, "The Black-Litterman Model for Active Portfolio Management," The Journal of Portfolio Management, Vol.35, No.2(2009), pp.61-70.

[22] Super Stock Screener, Available at http://www. superstockscreener.com/blog/2007/09/admin/ the-super-stock-screener-ranking-system/.

[23] Walters, J., "The Black-Litterman Model in Detail," Harvard Management Company, 2009.

[24] Wicas, N., "The Case of Structured Equity : An Active Quantitative Investment Strategy," Vanguard Investment Counselling and Research, 2006.

[25] Yanou, G., "The Black-Litterman Model Wrong Views v.s. Opportunity Cost," Available at SSRN : http://ssrn.com/abstract=1722237, 2010. 